\title{
Water balance component analysis of a spring catchment of western Nepal
}

\author{
J. K. K.C. $\odot^{1 *}$ S. Dhaubanjar $\circledast^{2}$, V. P. Pandey $\circledast^{3}$ and R. Subedi $\odot^{4}$ \\ Received : 10, April, $2021 \quad$ Revised : 10 May, 202 \\ Accepted : 26, May, 2021 \\ Published : 30, May, 2021
}

Springs in the mountains and hills are getting affected by both climatic and non-climatic changes. Hydrologic models are used to simulate the response of spring systems to the changes; however, only a limited number of studies using the hydrologic modeling approach have been accomplished on studying springs and spring-dominated watersheds in Nepal. This research aimed at understanding changing hydrological processes through hydrologic modeling in a spring catchment. A micro-catchment named 'Sikharpur' of West Seti watershed of Nepal was selected to get insights into the process influencing the spring system. The RRAWFLOW models with gamma distribution and time variant IRFs were calibrated and validated for the catchment to get the best fit model. The discharge was simulated according to the future projected climate scenarios. Then, a water balance was assessed for the micro-catchment. The results showed that understanding of likely response of hydrologic variables to potential future climate scenarios is critical for water resource management. It was estimated that the spring discharge would be decreased by more than 40 percentage after 50 years mainly due to the increase in evapo-transpiration ( $91.47 \%$ of the precipitation). Evapo-transpiration was found as a major hydrologic process impacting upon water balance in the spring catchment; therefore, its management for better spring resource conservation is recommended by considering high evapo-transpiration months, water deficient period and crop factor. The change in the storage was observed to be $51.78 \%$; so, detail isotopic analysis and long-term monitoring of water balance is required for further characterization of water balance components.

Keywords: Climate change, evapo-transpiration, hydrologic model, Nepal, RRAWFLOW, spring micro-catchment

$\mathrm{D}$ rying up of springs and water scarcity issues underscore the need to increase the understanding of spring hydrology, especially in the Himalayan region. It is realized that climate change impacts more on developing countries because they have a lesser capacity to adapt and have other stresses. Many studies in these regions show high water stress, and there is no sign of decreasing the effects in future. In a review of micro-scale and mesoscale studies, Negi (2002) stressed on the systematic monitoring to aid the management of Himalayan springs. Himalayan regions are one of the least monitored areas in terms of hydro-meteorological information (Agarwal et al., 2012). Bruijnzeel \& Bremmer (1989) and Alford (1992) elucidated that the management plans stemming from inadequate understanding would not solve water scarcity challenges. In order to improve water availability for the rural communities in

1 Program Officer, Freshwater, WWF Nepal, Baluwatar, Kathmandu.*Email: jibeshkc2012@gmail.com;

2 Sustalndus PhD Fellow, Mountain Hydrology, Water and Air, ICIMOD, Nepal;

3 Regional Researcher - Water \& Climate, International Water Management Institute, Nepal; and

4 Assistant Professor, Tribhuvan University, Institute of Forestry, Pokhara, Nepal. 
the Himalayan region, it is, generally, felt that there is a need to study these critical resources; however, only a limited number of studies using the hydrologic modeling approach have been accomplished on studying springs and springdominated watersheds in Nepal.

Spring is an important source of water supply in the Nepalese mountains because of its ease of access in the nearby rural communities, availability during short-term climatic variability and good quality compared to the surface-water located in the valleys. However, understanding spring system and associated hydrological process, such as, groundwater recharge have long been one of the most difficult challenges in data-scarce countries like Nepal. Given a certain set of favorable topographic and geological conditions in the catchment, spring may emerge as a result of flow through unconfined stratum or through fissures, cracks and other geological features in a confined stratum (Matheswaran et al., 2017). Although there exists considerable uncertainty about the climate change impacts in Nepal, increased temperature and changes in timing, magnitude, and intensity of monsoonal rainfall patterns are predicted to occur. Spring being the primary source of water resources for the rural communities perched at elevated locations in the Nepalese hills, it is imperative to address the challenges in the management of spring system and to devise ways to sustainably manage it under climate change. This requires a better understanding of key surface and subsurface hydrological components, and processes' controlling the spring system.

Hydrologic modeling aims to have a more global approach to understanding the behavior of watershed systems to make better predictions and to face the major challenges in water resource management. In spring hydrology, discharge reflects the complex interactions between the weather and the biophysical environment as water flows through hydrologic cycle. Hydrological processes can be simply described as a water balance equation to express the contributions of hydrologic processes to a stream-flow. The approach allows an examination of the hydrologic cycle for any period of time. The objective of this research is to understand the climatic trend in western Nepal and assess their effects on prevailing hydrologic processes and water balance components in a monitored spring microcatchment.

\section{Materials and methods}

\section{Study area}

The study on the spring hydrology was conducted in the Sikharpur micro-catchment under the West Seti Watershed Area situated in the Sigash Village Municipality-1 of Baitadi district of western Nepal (Figure 1), one of the most climate-vulnerable districts in the country. The study was carried out between July, 2017 - July, 2018.

With the total area of 86.9 ha, the study area is located between $29^{\circ} 28^{\prime} 46.70^{\prime \prime}$ - 29'29'40.70" $\mathrm{N}$ latitudes and between $80^{\circ} 41^{\prime} 16.85^{\prime \prime}$ $80^{\circ} 41^{\prime} 54.78^{\prime \prime} \mathrm{E}$ longitudes. The altitude of the terrain ranges from $1850 \mathrm{~m}$ to $2430 \mathrm{~m}$ above the mean sea level (Figure 1). The general geology of Sikharpur consists of phyllite and limestone, and springs are located near the contact of underlying quartzite and phyllite, and overlying limestone. There is high pressure on forest resources and it has been converted to other land uses and the site also experience noticeable climate extremes including prolonged drought, less and intense rainfall, declining water flow in the springs (Poudel et al., 2021). Topography of the area includes stable steep slopes, rocky land and terrace agriculture. Most of the area under the catchment is covered by some kind of vegetation $(83.78 \%)$ dominated by Kharland ${ }^{l}(31.06 \%)$ followed by the cultivated terraces $(26.79 \%)$ and sparse vegetation $(19.89 \%$, Figure 2 \& Table 1). The Quercus tree species were found in the upstream area of the catchment while the pines were found in the downstream area.

The water from the springs of the microcatchment had been harnessed through the direct diversion pipe system. Altogether, 453 inhabitants used the spring sources for drinking, bathing, livestock feeding, irrigation, and hydroelectricity generation.

\footnotetext{
1 Kharland area is a land that is used for grazing in upland areas. Often termed as Kharka land or Kharka area.
} 


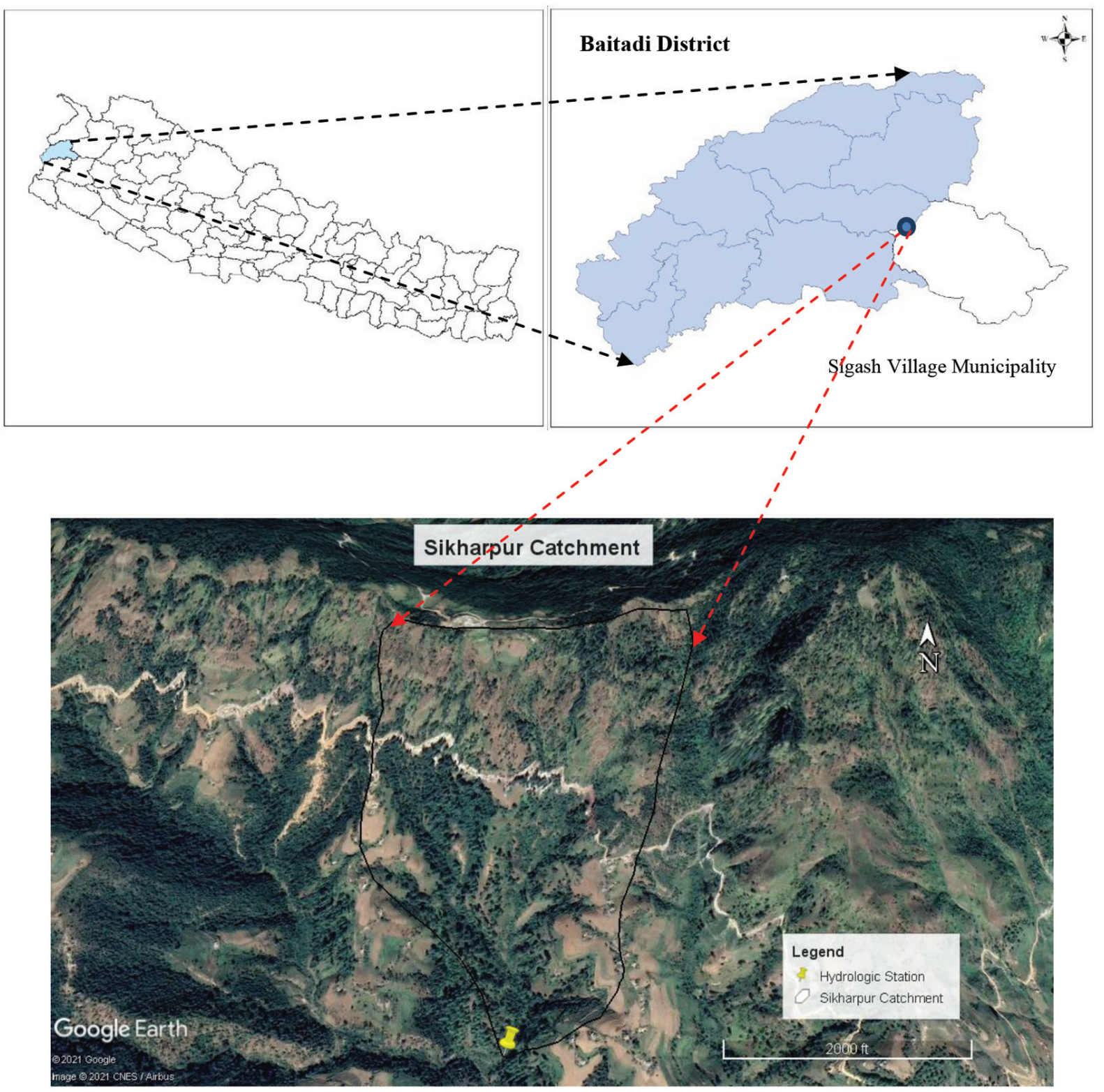

Figure 1: Location of the study area in the map of Nepal

Table 1: Land Use and Land Cover (LULC) Area by Type

\begin{tabular}{clrr}
\hline S. & LULC Type & Area (ha) & \% \\
N. & & 5.24 & 6.04 \\
1 & Dense forest & 17.26 & 19.89 \\
2 & Sparse vegetation & 26.94 & 31.06 \\
3 & Kharland & 23.24 & 26.79 \\
4 & Terraces (cultivated) & 2.15 & 2.48 \\
5 & Terraces (fallow) & 1.36 & 1.57 \\
6 & Settlement & 7.67 & 8.84 \\
7 & Barren & 2.89 & 3.33 \\
8 & Other & & \\
\hline
\end{tabular}




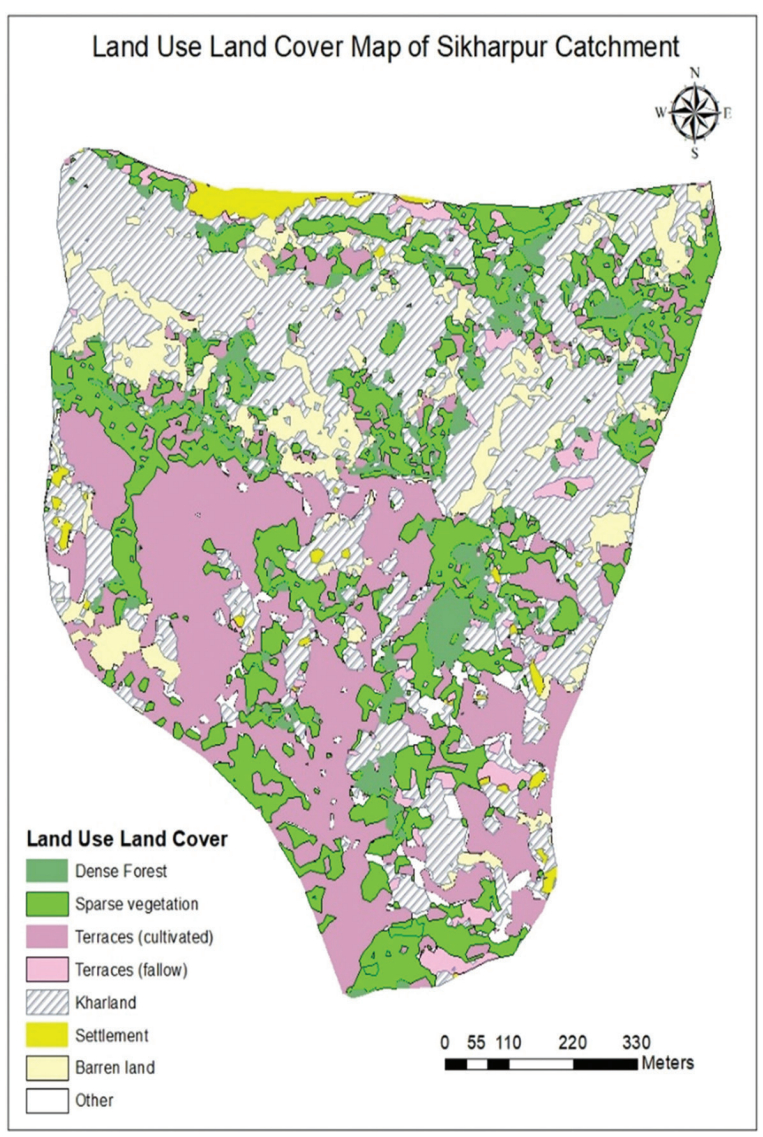

Figure 2: Land Use and Land Cover Map of Sikharpur Catchment \{Data source: Highresolution resource mapping of LULC for BCRWME project area (IWMI, 2019)\}

\section{Data collection}

The Sikharpur micro-catchment falls under the project-area of the "Building Climate Resilience in Watersheds of Mountain Eco-regions" (BCRWME) Project. As a part of the project, International Water Management Institute (IWMI) Nepal conducted a comprehensive research study titled, "Watershed Hydrology Impact Monitoring Research in Far West Nepal". IWMI, Nepal set up a hydro-meteorological monitoring station in the Sikharpur Village in order to monitor the weather parameters and spring flow. This study is financially supported by IWMI Nepal and the daily hydro-meteorological data during the period of $1^{\text {st }}$ May, $2016-23^{\text {rd }}$ June, 2018 were obtained from the stations for the purpose of this study.

For climate change analysis, the data from the local hydro-climatic station is not adequate. Therefore, the climatic data were collected from the nearby meteorological station at Patan situated at $1266 \mathrm{~m}$ elevation in Baitadi district; the daily maximum and minimum temperatures as well as the daily precipitation data during the aforementioned period were used for climate change analysis. The schematic flow followed during the study is presented below in Figure 3.

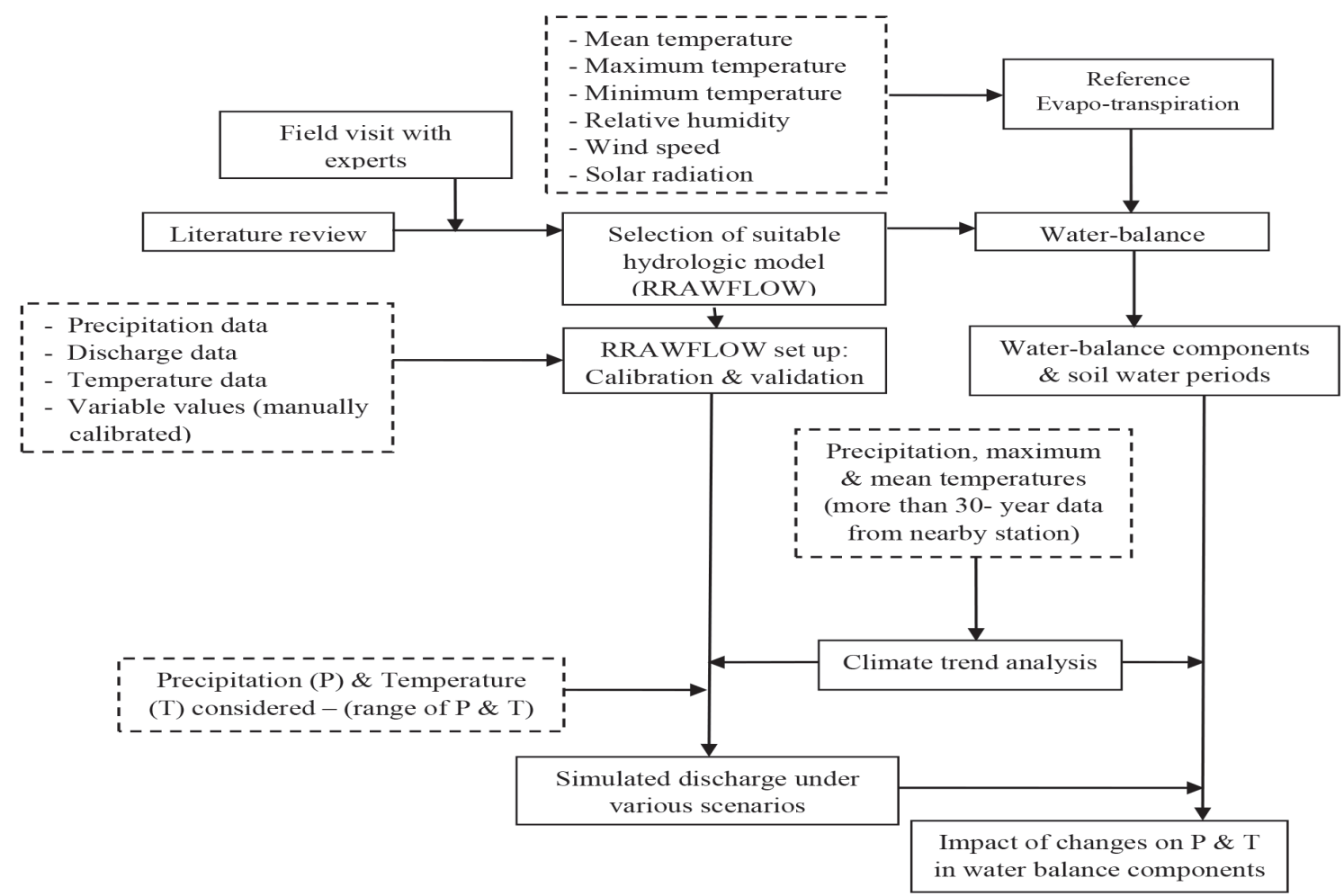

Figure 3: Flowchart showing the methodological framework of the study 


\section{Development and application of hydrological models}

\section{Hydrologic model selection}

A field visit with the experts was performed to know the spring system and catchment area, and also discussions were conducted to find out an appropriate model applicable for the microcatchment area under study. The available literatures and the associated models were reviewed keeping into consideration the lack of the data concerned with the weather characteristics, micro-watershed (small in area), available input variables and their characteristics (land use \& land cover map of $2 \mathrm{~m} \times 2 \mathrm{~m}$ resolution and two years' precipitation \& discharge), hilly area, spring discharge and local hydrogeology of the study area. After careful review and discussions, the Rainfall - Response Aquifer and Watershed Flow (RRAWFLOW) Model, and water balance approach were considered for application.

\section{Description of RRAWFLOW Model}

The RRAWFLOW is a lumped model that simulates response of stream flow, groundwater level, and solute transport or cave drip for a measurement place from the input of precipitation, recharge or solute. The model includes a time-series process to assess recharge from precipitation, and simulates the response from the convolution like in the unit-hydrograph approach.

A discrete form of the convolution integral for uniform time steps used in RRAWFLOW (Long, 2014) is:

$y_{i}=\Delta t \sum_{i=0}^{j} h_{i-j} u_{j}+\varphi_{i} \quad i, j=0,1, \ldots, N$

Where, $\mathrm{y}_{\mathrm{i}}$ is the system response; is the change in time; $h_{i-j}$ is the Impulse Response Function (IRF); is the input; $j$ and $i$ are time-step indices corresponding to system input and output, respectively; $\mathrm{N}$ is the number of time steps in the output record; $\varphi_{i}$ represents the errors resulting from measurement inaccuracy, sampling interval, or simplifying model assumptions. The quantity $\mathrm{i}-\mathrm{j}$ represents the time duration from impulse to response, and the IRF represents a distribution of these delay times. Physically, IRF is the system response $\left(y_{\mathrm{i}}\right)$ per unit impulse of input $\left(\mathrm{u}_{\mathrm{j}}\right)$ and also can be described as the response produced by a system when the input is a delta function (Smith, 2003). Conceptually, convolution is the superposition of a series of IRFs that are initiated at the time of each impulse of $u_{j}$ and are scaled proportionally by the magnitude of the corresponding impulse.

Model outputs consist of time series for simulated discharge, the IRFs (dry and wet), the soilmoisture index, and the input to convolution. Other outputs consist of a coefficient of efficiency "E" to measure the similarity between the simulated and observed system response (residuals) and the hydrological memory of the system. The simulation period for Sikharpur was from $1^{\text {st }}$ May, 2016 to $31^{\text {st }}$ May, 2017 followed by the validation period which ended on $23^{\text {rd }}$ June, 2018.

\section{Prediction of discharge under changing climatic scenarios}

The climate trend analysis was accomplished to find out the projected change in temperature and precipitation in future. The future discharge was predicted from the best fit model by applying the changed temperature and precipitation in the RRAWFLOW Model.

\section{Estimating water balance components}

\section{Water balance equation}

Water balance components include precipitation, discharge, evapo-transpiration and soil water storage for a spring catchment. For the purpose of this study, the precipitation and discharge data from the local meteorological and hydrological stations within each micro-catchment were used for the water balance analysis.

The reference evapo-transpiration was assessed using the Evapo-transpiration (ETo) Calculator based on the FAO Penman-Monteith Equation. Allen et al. (1998) recommended the FAO 
Penman-Monteith method as a new standard for reference evapotranspiration and also provided guideline for calculating various parameters under the method. In this study, crop coefficient was not included to calculate the evapo-transpiration as most of the area under the catchment was covered by some kind of vegetation $(83.78 \%)$, which reflect the ideal situation to use reference evapo-transpiration ( Figure $2 \&$ Table 1).

The data used for the calculation of evapotranspiration were: the mean monthly temperature data (min, max and mean), solar radiation, wind speed, and relative humidity. The water consumption by the users was calculated by multiplying daily consumption per person with the total population dependent on the water source. WHO (2011) illustrates water requirement quantity of a person ranges from 7.5 to 15 liters per day (lpd) including need of survival, basic hygiene practices and basic cooking needs. This study used the least water requirement per person (7.5 lpd) for characterizing water balance as additional water sources are also available nearby the Sikharpur catchment.

\section{Results}

\section{Calibration and Validation of RRAWFLOW}

The best-fit model for Sikharpur micro-catchment was explored by conducting hundreds of manual optimization of variables (Figure 4). Gamma distribution and IRFs were found to be appropriate for the modeling. Four IRFs including two of dry mean years and the rest two of the wet years were fitted in the best mode fit.

The model was found to be appropriate for the prediction of discharge from precipitation and temperature in the Sikharpur catchment (Table). Also during the calibration and validation periods, only a very little difference was observed in the model efficiency, indicating a good model fit (Table 2).

Table 2: Model calibration and validation statistics

\begin{tabular}{cccccc}
\hline & From & To & $\mathbf{R}^{2}$ & P-BIAS & NSE \\
\hline $\begin{array}{c}\text { Simulation } \\
\text { Period }\end{array}$ & $\begin{array}{c}1^{\text {st }} \text { May, } \\
2016\end{array}$ & $\begin{array}{c}22^{\text {nd }} \text { Jun, } \\
2018\end{array}$ & 0.73 & 4.9 & 0.73 \\
$\begin{array}{c}\text { Calibration } \\
\text { Period }\end{array}$ & $\begin{array}{c}1^{\text {st }} \text { May, } \\
2016\end{array}$ & $\begin{array}{c}31^{\text {st }} \text { May, } \\
2017\end{array}$ & 0.74 & 0.3 & 0.72 \\
$\begin{array}{ccccc}\text { Validation } \\
\text { Period }\end{array}$ & $\begin{array}{c}1^{\text {st }} \text { Jun, } \\
2017\end{array}$ & $\begin{array}{c}22^{\text {nd }} \text { Jun, } \\
2018\end{array}$ & 0.72 & 2.9 & 0.72 \\
\hline
\end{tabular}

Note: Nash-Sutcliffe model efficiency coefficient (NSE) is used to assess the predictive skill of hydrological models. PBIAS is percent bias, and $\mathrm{R}^{2}$ is coefficient of determination.

\section{Climate Change and Spring Discharge}

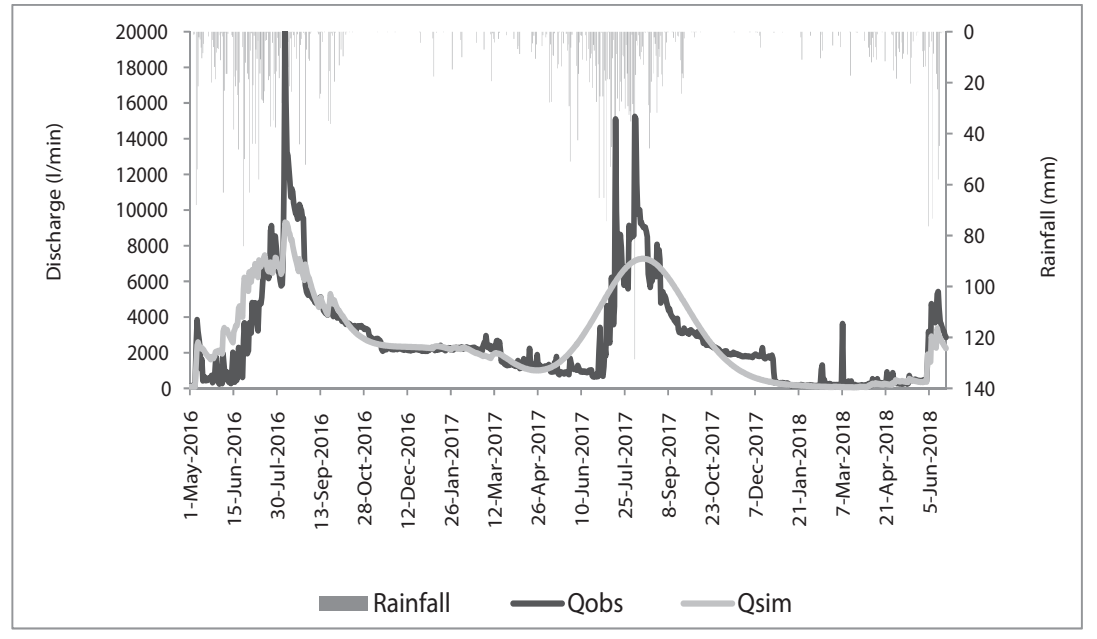

Figure 4: Best Fit Model for Sikharpur micro-catchment
At Sikharpur, the average mean temperature was found tobe $18.6^{\circ} \mathrm{C}$ with anincreasing trend of mean temperature at the rate of $0.024^{\circ} \mathrm{C}(0.13 \%$ every year) and also a sharp decline in minimum and mean temperatures in 2002 (Figure 5). The average annual rainfall at Sikharpur was found to be $1366 \mathrm{~mm}$ with an increasing trend of rainfall by only $0.56 \mathrm{~mm} /$ year $(0.04 \%$ per year $)$ with frequent fluctuations (Figure $6)$. 


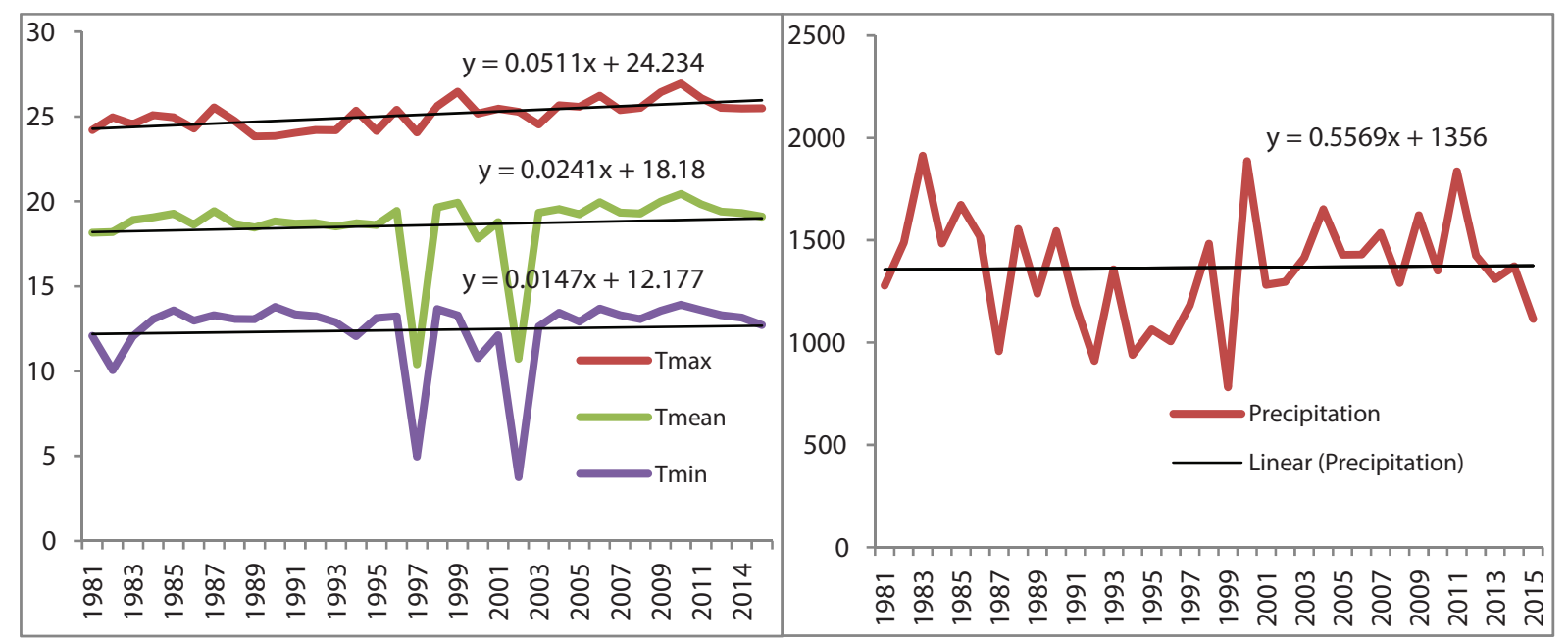

Figure 5: Temperature trend at Sikharpur

Figure 6: Rainfall trend at Sikharpur

A decreasing trend was noticed in discharge in future climatic scenario by $0.84 \%$ after one year, by $1.74 \%$ after two years, by $9.51 \%$ after 10 years, by $31.66 \%$ after 30 years, and by $40.48 \%$ after 50 years (Table 3).

Table 3: Future climate scenario and change in discharge

\begin{tabular}{|c|c|c|c|}
\hline Description & $\begin{array}{l}\text { Total discharge } \\
\text { for } 784 \text { days } \\
\text { (liter/min) }\end{array}$ & $\begin{array}{c}\text { Average Yearly } \\
\text { discharge(liter/min) }\end{array}$ & $\begin{array}{l}\% \text { change in discharge (based } \\
\text { on simulated discharge by best- } \\
\text { fitted model) }\end{array}$ \\
\hline Measured discharge & 2103466.44 & 980633.91 & \\
\hline Simulated discharge & 2189840.55 & 1020901.43 & \\
\hline Projected discharge after 1 year & 2171347.52 & 1012280.00 & -0.84 \\
\hline Projected discharge after 2 years & 2150864.43 & 1002730.80 & -1.78 \\
\hline Projected discharge after 3 years & 2130482.06 & 993228.56 & -2.71 \\
\hline Projected discharge after 4 years & 2108820.52 & 983129.97 & -3.70 \\
\hline Projected discharge after 5 years & 2087287.85 & 973091.46 & -4.68 \\
\hline Projected discharge after 10 years & 1981547.51 & 923795.42 & -9.51 \\
\hline Projected discharge after 20 years & 1744067.11 & 813082.31 & -20.36 \\
\hline Projected discharge after 30 years & 1496456.13 & 697646.32 & -31.66 \\
\hline Projected discharge after 50 years & 1303445.81 & 607665.11 & -40.48 \\
\hline
\end{tabular}

\section{Estimating water balance components}

The water balance equation for the Sikharpur micro-catchment can be presented as:

Change in Storage $=$ Inflow - Outflow

Change in Storage $=$ Precipitation $-($ Discharge or Runoff + Evapo-transpiration + Consumption)
Or,

The total evapo-transpiration for the entire period of 26 months (2.14 years) was $2.5689 \times 10^{3} \mathrm{~mm}$, precipitation $2.8085 \times 10^{3} \mathrm{~mm}$ and runoff $0.190 \times 10^{3}$ $\mathrm{mm}$. The water consumption of water by 453 users of Sikharpur was found to be $3.065 \times 10^{3} \mathrm{~mm}$ (@) 7.5 liters per person per day as per the WHO, 2011). Based on these figures, the change in the 
storage value was found to be $-3.015 \times 10^{3} \mathrm{~mm}$ for 26 months (Table 4). On an average, annually $1.312 \times 10^{3} \mathrm{~mm}$ precipitation fell in the Sikharpur micro-catchment, $1.20 \times 10^{3} \mathrm{~mm}$ evaporated from the catchment, $1.429 \times 10^{3} \mathrm{~mm}$ consumed by the users and $0.089 \times 10^{3} \mathrm{~mm}$ flew as runoff through the spring sources and turned as discharge. Therefore, the change in the storage was found to be $-1.405 \times 10^{3}$ $\mathrm{mm} /$ year. The total outflow in the system for the whole period was found to be $5.824 \times 10^{3} \mathrm{~mm}$.

Table 4: Water balance components of Sikharpur micro-catchment

\begin{tabular}{|c|c|c|}
\hline \multirow{2}{*}{$\begin{array}{c}\text { Water balance } \\
\text { component }\end{array}$} & \multicolumn{2}{|c|}{ Values in period } \\
\hline & $\begin{array}{c}2 \text { yrs. and } 2 \\
\text { months }\end{array}$ & 1 year \\
\hline Precipitation $(\mathrm{P}), \mathrm{mm}$ & 2808.49 & 1312.40 \\
\hline Evapo-transpiration (E), & & \\
\hline $\mathrm{mm}$ & 2568.91 & 1200.40 \\
\hline Runoff (R), mm & 189.92 & 88.75 \\
\hline Total Inflow (I), $\mathrm{mm}=\mathrm{P}$ & 2808.49 & 1312.40 \\
\hline Total Outflow $(\mathrm{O}), \mathrm{mm}=$ & & \\
\hline $\mathrm{E}+\mathrm{R}+\mathrm{C}$ & 5824.00 & 2715.14 \\
\hline Change in storage $(\mathrm{S})$, & & \\
\hline $\mathrm{mm}$ & -3015.51 & -1405.83 \\
\hline Consumption (C), mm & 3065.17 & 1428.98 \\
\hline Runoff Ratio (P/R) & & 14.79 \\
\hline Runoff (\%) & & 6.76 \\
\hline Evapo-transpiration (\%) & & 91.47 \\
\hline Change in storage $(\%)$ & & -51.78 \\
\hline
\end{tabular}

The Residence Time $(\mathrm{RT}=\mathrm{S} / \mathrm{O})$ was found to be 25 minutes and 55 seconds which means on an average, the given water parcel remained for about 26 minutes as storage in the Sikharpur micro-catchment. The Runoff Ratio (P/R) was found to be 14.79 or $6.76 \%$ which indicated that 14.79 fraction or $6.76 \%$ of the precipitation appeared as runoff in the spring catchment, and became spring discharge after evaporation loss and consumption by the users. Moreover, $91.47 \%$ of the total precipitation was found to have evaporated in the atmosphere, which is the very big portion of the precipitation. However, a significant negative change in storage, i.e., -51.78 indicated a big amount of groundwater inflow (Table 4).

We found evapotranspiration to be a major influencing hydrologic process, therefore, it would be relevant to explore it in more detail. Monthly reference evapotranspiration was found minimum $2.35 \mathrm{~mm}$ /day to a maximum $4.93 \mathrm{~mm}$ /day (Figure 7). The evapotranspiration was higher $(>4.00 \mathrm{~mm} /$ day $)$ in the months of October, March, April and May, highest (4.93 $\mathrm{mm}$ /day) being in mid-May. It was low (around $2.35 \mathrm{~mm} /$ day) in the months of July, August, November and December. For the study area, the period from mid-May to mid-September was found to be the "soil water recharge period" followed by the period from mid-September to mid-October as "soil water utilization period", and mid-November to mid-May was found "water deficient period" (Figure 7).

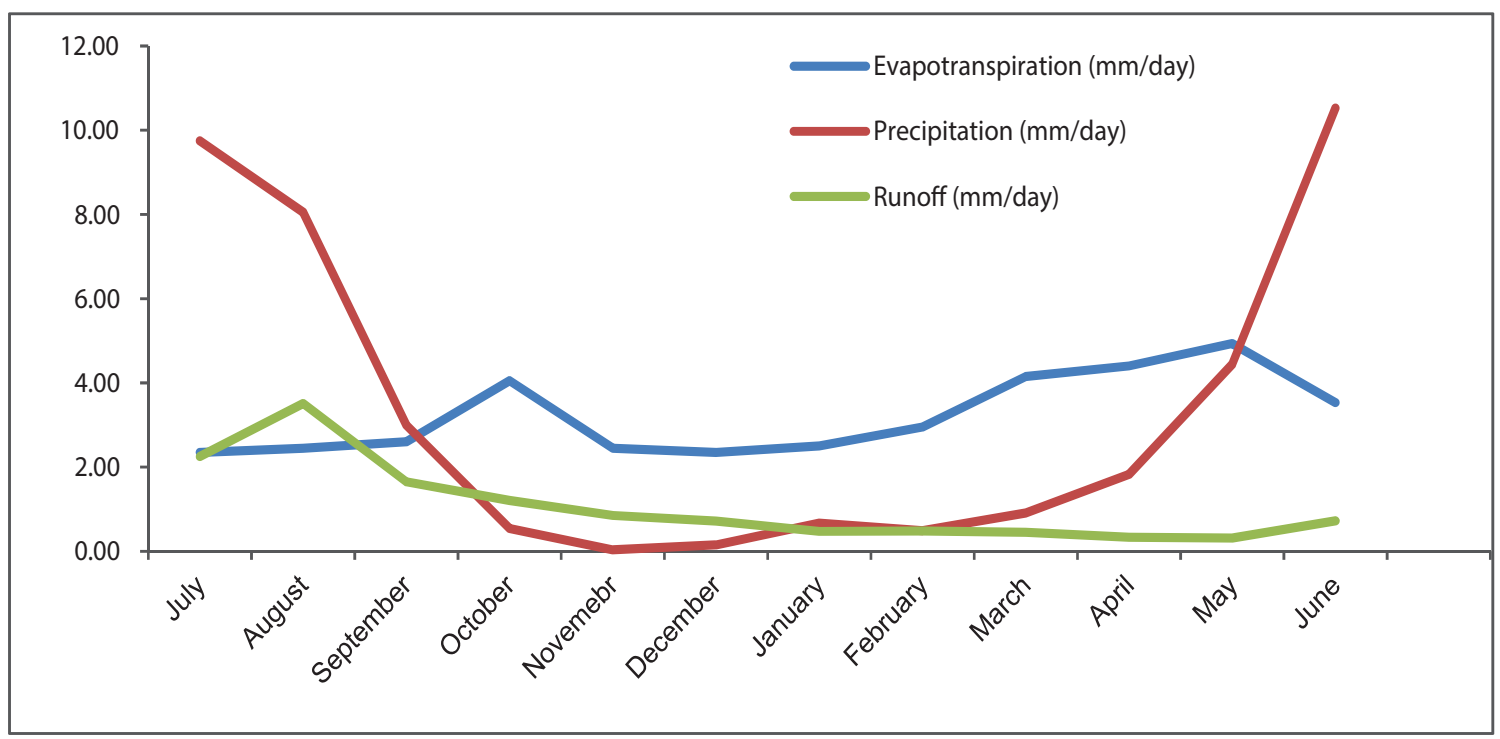

Figure 7: Water Balance Graph including runoff for Sikharpur micro-catchment 


\section{Discussion}

Like elsewhere in the world, the increasing trend of temperature was observed in the study area. The increase in precipitation was observed with very little volume, and the frequent fluctuations indicated erratic rainfall as experienced in other parts of the country and the world. Very big portion of precipitation ( $>90 \%$ ) was found to have evaporated from the spring hydrologic system. It is high in comparison to the continental United States where approximately two-third of all rainfall delivered is lost due to evapotranspiration (US WRC, 1978).

Based on the water balance study, another big volume of water inflow as groundwater inflow was predicted, which was also indicated by Chinnasamy \& Prathapar (2016) in the microcatchment. A nearby area was identified by the duo researchers as potential spring shed; however, they were unable to quantify the area. Isotope analyses, particularly water dating and stable isotope investigations, can be a best method to access recharge areas outside a watershed, as they have ability to assess complex spring systems including connection between aquifers.

The monthly reference evapo-transpiration at Sikharpur was found to be similar to the other parts of the country ranging from minimum in July to maximum in December. Among others, some months were observed as having higher evapo-transpiration, i.e., October, March, April, and May. In addition, the "soil water recharge period", the "soil water utilization period" and the "water deficient period" observed in the study area represented a typical example of far-west Nepal.

In this study, crop coefficient was not included to calculate the evapo-transpiration as more than $83 \%$ of the catchment is covered by some kind of cover. The crop coefficient includes effect of typical vegetation on evapo-transpiration which is different from the effect of the ideal grass reference that depicts continuous grass presence with complete cover (FAO, 1998). Consequently, different crops have different effect on evapo- transpiration. Crop factor can influence evapotranspiration by the crop-height, albedo (reflectance) of the crop-soil surface, aerodynamic properties, leaf and stomata properties, canopy resistance and evapo-transpiration from soil. Following soil wetting, the vapor transfer rate from the soil is high, especially for crops having incomplete ground cover (FAO, 1998).

\section{Conclusion and recommendations}

While analyzing the future climatic scenario based on the RRAWFLOW's best fit model of the Sikharpur micro-catchment, it was estimated that the discharge will be decreased by $40.48 \%$ after 50 years in the micro-catchment. The erratic change in precipitation (increase by $0.04 \%$ per year) and gradual increase in temperature (by $0.13 \%$ per year) resulted in the decreasing spring discharge. The RRAWFLOW Model with four time-invariant IRFs and gamma distribution (NSE=0.73) was found best for the prediction of discharge from precipitation, and portraits the behavior of the Sikharpur spring micro-catchment quite good.

More than $90 \%$ of the precipitation was found to have evaporated from the catchment, which is a very big portion of the precipitation. Therefore, its management for spring resource conservation is recommended by this study. The months of October, March, April, and May were found to have higher evapo-transpiration $(>4.00 \mathrm{~mm} /$ day) while the months between September and May were observed as the water deficient period at Sikharpur. Apart from these, crop factor also need to be considered for better management of spring catchment areas.

Almost $52 \%$ of negative change in the storage was found at the study site. Therefore, the groundwater inflow was also predicted as one of the determinant hydrologic processes for spring discharge in this study. However, further detail isotopic analysis (to find recharge areas) and long-term monitoring of water balance are recommended for further characterization of water balance components. 


\section{References}

Agarwal, A., Bhatnaga, N. K., Nema, R. K. and Agrawal, N. K. (2012). Rainfall Dependence of Springs in the Midwestern Himalayan Hills of Uttarakhand. Mountain Research and Development 32 (4): 446-455. https://doi.org/10.1659/MRDJOURNAL-D-12-00054.1

Alford, D. (1992). Streamflow and sediment transport from mountain watersheds of the Chao Phraya Basin, northern Thailand: A reconnaissance study. Mountain Research and Development 12 (3): 257-268.

Allen, R. G., Pereira, L. S., Raes, D. and Smith, M. (1998). Crop evapo-transpiration Guidelines for computing crop water requirements. FAO Irrigation and Drainage Paper No 56. Rome, Italy. 300 pp.

Bruijnzeel, L. A. and Bremmer, C. N. (1989). Highland-lowland interactions in the Ganges Brahmaputra River Basin: A review of published literature. ICIMOD Occasional Paper No. 11. Kathmandu, Nepal: International Centre for Integrated Mountain Development (ICIMOD). 152p

Chinnasamy, P. and Prathapar, S.A. (2016). Methods to investigate the hydrology of the Himalayan springs: a review. Colombo, Sri Lanka: International Water Management Institute (IWMI). (IWMI Working Paper 169). 28p. doi:10.5337/2016.205

FAO (1998). Crom evapo-transpiration Guidelines for computing crop water requirements - FAO Irrigation and drainage paper 56. Food and Agriculture Organization of the United Nations, Viale delle Terme di Caracalla, 00100 Rome, Italy. M-56, ISBN 92. ISBN 92-5-1042195. http://www.fao.org/3/x0490e/x0490e0b .htm\#TopOfPage

Grabs, W. E. and Pokhrel, A.P. (1992). Establishment of measuring service for snow and glacier hydrology in Nepal:
Conceptual and operational aspects. In: International Symposium on Snow and Glacier Hydrology, G.J. Young (ed.). Kathmandu, Nepal: International Association of Hydrological Sciences (IAHS). pp 3-16.

IWMI. (2019). Characterization of SpringDominated Micro-Watersheds in Western Nepal-The Case of Springs in Shikharpur and Banlek. International Water Management Institute (IWMI): Colombo, Sri Lanka, 2019.

Long, A. J. (2014). RRAWFLOW: Rainfallresponse Aquifer and Watershed Flow Model (v1.11). Geoscientific Model Development. pp. 5919-5963. https://doi. org/10.5194 /gmdd-7-5919-2014

Matheswaran, K., Dhaubanjar, S., Pandey, V. P. and Bharathi, L. (2017). Literature review of models for understanding hydrology of spring system in Western Nepal. International Water Management Institiute, Colombo, Srilanka, December 2017. pp 1-19.

Negi, G.C.S. (2002). Hydrological research in the Indian Himalayan Mountains: Soil and water conservation. Current Science 83 (8): 974-980.

Poudel, J. Sudehi, R. Khadka, A. and Okwany, R. (2021). Impact of Forest Cover, Land Use Change and Climate Change on Water Availability: Scenario of Water Use Practices in the Mountains of Nepal. Unpublished.

US WRC (1978). The Nation's Water Resources, 1975-2000: Second national water assessment. The US Water Resource Council, Washington, DC. pp. 1-64.

WHO (2011). Guidelines for drinking-water quality, $4^{\text {th }}$ edition. World Health Organization, Geneva. http://www.who. int/water_sanitation_health/publications/ 2011/dwq_chapters/en/index.html 